\title{
The evaluation of Avian Influenza and Coronavirus as Pathogenic Enveloped Viruses for Possible Health Risk in Seafood: A Review
}

\author{
Bahar TOKUR* Koray KORKMAZ \\ ODU Fatsa Faculty of Marine Sciences, Fishing Tech. Eng. Department, Fatsa / Ordu, Turkey
}

How to cite: Tokur, B. \& Korkmaz, K. (2021). The evaluation of Avian Influenza and Coronavirus as Pathogenic Enveloped Viruses for Possible Health Risk in Seafood: A Review. J. Anatolian Env. and Anim. Sciences, 6(1), 31-42.

Atıf yapmak için: Tokur, B. \& Korkmaz, K. (2021). Su Ürünlerinde Patojenik Zarflı Virüsler Olarak Avian Influenza ve Koronavirüsün Olası Sağlık Riski Bakımından Değerlendirilmesi: Derleme. Anadolu Çev. ve Hay. Dergisi, 6(1), 31-42.

: https://orcid.org/0000-0002-7087-5801 iD: https://orcid.org/0000-0003-2940-6592

\begin{abstract}
Human pathogenic viruses in seafood are a significant and emerging problem for public health, food safety, and socio-economic implications worldwide. They may exist in any form of untreated water due to pollution induced by fecal content of human or animal origin, directly infected through interaction with body secretions and fluids containing contagious viral particles, or indirectly by aerosols or other polluted fomites. Thus, human pathogenic viruses can cause infection anytime by transmitting them from water and food environments to seafood and its products. Nowadays, people go through an unprecedented, huge challenge and global health disaster around the world because of the severe acute respiratory syndromecoronavirus-2 (SARS-CoV-2) outbreak. Non-enveloped viruses are commonly known to have more stable and can survive much longer than viruses with an envelope tag. However, some studies show that some enveloped viruses such as avian influenza can be accumulated by seafood and can survive at low temperature for a long time. Low temperature preservation of seafood during processing, storage, transfer, distribution and display in retail stores are common methods to prevent the loss of quality and survival of the SARS-CoV2 may be enough time to have all transmission routes at these low temperatures like other viruses. However, there have been no cases of COVID-19 infection identified through either water-borne or food-borne transmission since the beginning of the pandemic (almost a year). It seems that the main way of virus transmission is mostly person to person through respiratory droplets. So, it is thought to be that the risk of getting COVID-19 from seafood is very low and it can safely consume with proper cooking and hygiene protocol.
\end{abstract}

Keywords: Avian influenza, coronavirus, health risk, seafood.

\section{Bahar TOKUR}

ODU Fatsa Faculty of Marine Sciences.

Fatsa / Ordu, Turkey.

$凶$ : bahartokur@ odu.edu.tr

\section{Su Ürünlerinde Patojenik Zarflı Virüsler Olarak Avian Influenza ve Koronavirüsün Olası Sağık Riski Bakımından Değerlendirilmesi: Derleme}

*Sorumlu yazar: Bahar TOKUR

ODÜ Fatsa Deniz Bilimleri Fak.

Balıkçılık Tekn. Müh. Bölümü,

Fatsa/ORDU TÜRKIYE

凶: bahartokur@odu.edu.tr
Öz: Su ürünlerinde patojenik virüsler, dünyada gıda güvenliği, halk sağlı̆̆ı ve sosyo-ekonomik etkiler bakımından önemli bir sorundur. Bu virüsler, insan veya hayvan kaynaklı dışkı içeriğinin neden olduğu herhangi bir arıtılmamış su kaynağında, doğrudan bulaşıcı viral partiküller içeren vücut salgıları ve sıvılarıyla veya dolaylı olarak aerosoller veya diğer kirli materyallerle enfekte olan bulaşma nedeniyle bulunabilirler. Böylelikle insan patojenik virüsleri, her an su ve gıda alanlarından su ürünlerine bulaşarak enfeksiyona neden olabilirler. Günümüzde insanlar, şidetli akut solunum sendromu- koronavirüs-2 (SARS-CoV-2) salgını nedeniyle tüm dünyada benzeri görülmemiş, büyük bir zorluk ve felaket yaşamaktadır. Genellikle, zarfsız virüslerin daha kararlı olduğu ve zarflı virüslerden çok daha uzun süre hayatta kalabileceği bilinmektedir. Bununla birlikte, bazı çalışmalarda kuş gribi gibi zarflı virüslerin deniz mahsullerinde birikebildiği ve düşük sıcaklıklarda daha stabil olduğu gösterilmiştir. Su ürünlerinin işlenmesi, depolanması, aktarılması, dağıtılmas s ve perakende mağazalarında sergilenmesi sırasında düşük sıcaklıkta korunması kalite kaybını önlemek için kullanılan yaygın bir yöntemdir ve SARS-CoV- 2 düşük sıcaklıklarda tüm bulaşma yollarıyla hayatta kalabilmek için yeterli zamana sahip olabilir. Bununla birlikte, salgın başladığından beri (yaklaşık bir yıl), su ya da gıda kaynaklı bulaş yoluyla belirlelen herhangi COVID-19 enfeksiyon vakası belirlenmemiştir.Virüsün yayılmasının ana yolunun çoğunlukla kişiden kişiye solunum damlacıkları yoluyla olduğu görülmektedir. Bu nedenle, COVID-19'u gıdalardan alma riskinin çok düşük olduğu ve su ürünlerinin uygun pişirme ve hijyen protokolleriyle güvenli bir şekilde tüketilebileceği düşünülmektedir.

Anahtar kelimeler: Koronavirüs, kuș gribi, sağlık riski, su ürünleri. 


\section{INTRODUCTION}

Seafood and water-related transmission may also be suspected of enhancing the spread and production of zoonotic respiratory viruses (e.g., influenza, severe acute respiratory syndrome-coronavirus (SARS-COV), severe acute respiratory syndrome-coronavirus-2 (SARS-COV2), Middle East Respiratory Syndrome-Coronavirus (MERS) and Nipah virus), facilitating the occurrence of zoonotic events with bushmeat (Ebola virus) handling (Liya et al., 2020; Ohimain, 2016; Qu et al., 2020; Wolfe et al., 2005). Highly Pathogenic Avian Influenza (HPAI) virus (H5N1) and SARS-CoV have been identified in the WHO study as having the possibility for spread from animals (WHO 2008). Avian influenza and coronavirus (SARS-COV and SARS-COV-2) as enveloped viruses are cause a significant and emerging food safety and public health problem and threat.

Coronaviruses (CoVs) have a diameter of 120-160 nm, non-segmented RNA genome between 26.4 and 31.7 kilobases, enveloped viruses with single-stranded and as the name implies "corona" (means crown), when seen under electron microscopy it has crowned like projections (Siddell, 1995). Within the envelope, there is the helical capsid composed of the RNA and genome nucleoprotein (Kampf et al., 2020; La Rosa et al., 2020b). The nonenveloped waterborne viruses such as adenoviruses, enteroviruses, coliphage, more commonly known for persistence and disinfection in water and wastewater, is different from the coronaviruses concerning the presences of having a lipid membrane and comparatively large ssRNA genome (Silverman \& Boehm, 2020). Coronavirinae family is separated into four genera named as alpha-, beta-, gamma-and delta-coronavirus. Only alpha (HCoV-229E and HCoV-NL63) and beta coronaviruses (HCoV-HKU1, HCoV-OC43, MERS-CoV and SARS-CoV) are recognized to infect humans and animals related to respiratory and gastro-intestinal infections (Cui et al., 2019; La Rosa et al., 2020c; Sharma et al., 2020). In late 2019, SARS-COV-2 as betacoronavirus has emerged and can lead to high mortality rates (Qu et al., 2020). This novel coronavirus (SARSCoV-2) outbreak called as COVID-19 has been announced a global pandemic by the World Health Organization (WHO) on March 11, 2020 (Qu et al., 2020; Randazzo et al., 2020).

Influenza is an extremely infectious respiratory illness, with several years of local clusters, with rare epidemics or pandemics. In the "Spanish" influenza pandemic of 1918-1919, Influenza viruses killed an estimated 20 to 50 million people worldwide (Tumpey et al., 2005). For a variety of reasons, the worldwide effect may be much greater this time (Webster, 1994). The influenza virus is common and can be seen in animals such as birds, horses, and pigs and also in humans, as sometimes cetaceans, dogs and mustelids can be infected from it as well. Generally, the natural hosts of certain avian influenza viruses are reservoirs in wild aquatic birds of the orders Anseriformes (e.g. ducks, geese, swans) and Charadriiformes (e.g. seagulls, terns, waders) (Hussain et al., 2016). Extremely pathogenic avian influenza (H5N1) has resulted in serious poultry and human illnesses. The Office International des Epizooties (OIE) and WHO recorded over 15,000 outbreaks of domestic birds from 2005 to 2018 and 861 human cases from 2003 to 2019 worldwide, respectively (Roy Chowdhury et al., 2019). Epidemics of avian influenza viruses from 68 countries were identified as of May 2019 (OIE, 2019).

This work will focus on the evaluation of avian influenza and coronavirus as human pathogenic enveloped viruses for possible health risks.

\section{POSSIBLE ROUTES OF TRANSMISSION}

The routes of transmission of seafood associated human pathogenic enveloped viruses are shown in Figure 1.

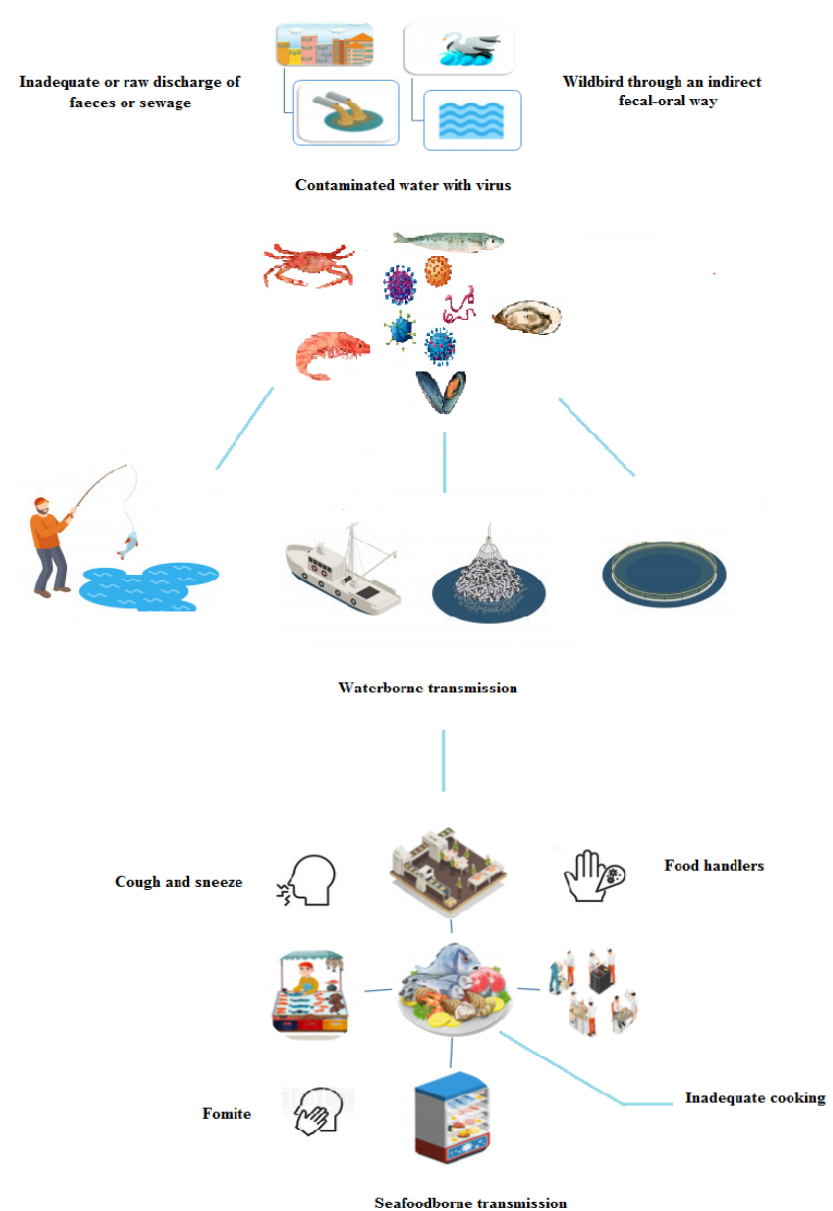

Figure 1. Routes of transmission of seafood associated human pathogenic enveloped viruses. 
Viruses are stable in the environment and can be spread through air, water, food or by direct or indirect contact with contaminated body fluids. Viruses can enter the body through numerous sites containing either the respiratory and enteric tracts by aerosolized droplets and droplet nuclei, or the fecal-oral (Yezli \& Otter, 2011). Over 140 types of pathogenic viruses can be transmitted from the aquatic environment (WHO, 1995). In the marine environment, all known seafood-borne pathogenic viruses caused an important public health hazard are transmitted via primarily the fecal-oral route, which regularly discharged to marine and estuarine waters either treated or untreated sewage (Griffin et al., 2003; Kovač et al., 2009) and urine, and respiratory secretions from the infected host which enter into sewage water (Wang et al., 2018). Various events such as floods, purified and untreated contaminated waste discharges or sewage flow can raise microbial contaminants in shellfish habitats. The bivalves are filter massive quantities of seawater and concenrate human pathogens (Bosch et al., 2005). Many species of seafood such as shrimps (Botero et al., 1996) or crabs (Goyal \& Nelson, 1984) can carry viruses in their shells, and infected bivalves can be feeding by carnivorous shellfish such as lobsters or crabs, or fish (Hejkal \& Gerba, 1981). In 2003, the WHO reported that the effect of waterborne infection of pathogens has caused 3.4 million deaths worldwide, while the EU reported that 13,548 children who were less than 14 die per year from these waterborne pathogens; nevertheless, it is impossible to measure the actual influence of viruses on all pathogens (Gibson, 2014).

Viral transmission can also occur through polluted seafood, due to insufficient hygienic activities by infected food handlers (Bosch et al., 2016; Koopmans, 2005; Seymour \& Appleton, 2001; Shao et al., 2011; Todd \& Grieg 2015), the aerosolized virus caused by infected persons (Koopmans \& Duizer, 2004; La Rosa et al., 2020b; Qu et al., 2020) and their contamination sites within the human body like nervous system (Enterovirus, Nipah virus, Poliovirus, Parechovirus), respiratory system (HPAI-H5N1, SARS-CoV, Liver HAV, HEV), neural tissue and, and intestinal system (NoV, HRV, Sapovirus, Astrovirus, Adenovirus, Aichi virus) (WHO, 2008). The very first foodborne infection is a way to spread among the human population, which can then change and spread itself through person-to-person infection. Contaminated raw materials or fresh products are available from remote locations and can be used as ingredients in many types of food, thus raising the possibility for the spread of infection and the effects in the food industry (Bosch et al., 2018). Various the reported cases of foodborne virus disease have been related to infection of convenience, ready-to-serve food by a contaminated food handler, according to WHO reports (WHO, 2008).

\section{AVIAN INFLUENZA (A)}

Influenza A viruses are members of the Orthomyxoviridae family of one-stranded, negative-sense enveloped RNA viruses (Figure 2). These are classified as 18 haemagglutinin and 11 subtypes of neuraminidase (NA) (Palese \& Shaw, 2007). Electron microscopy of isolated influenza (H1N1) virus particles is shown in Figure 2.
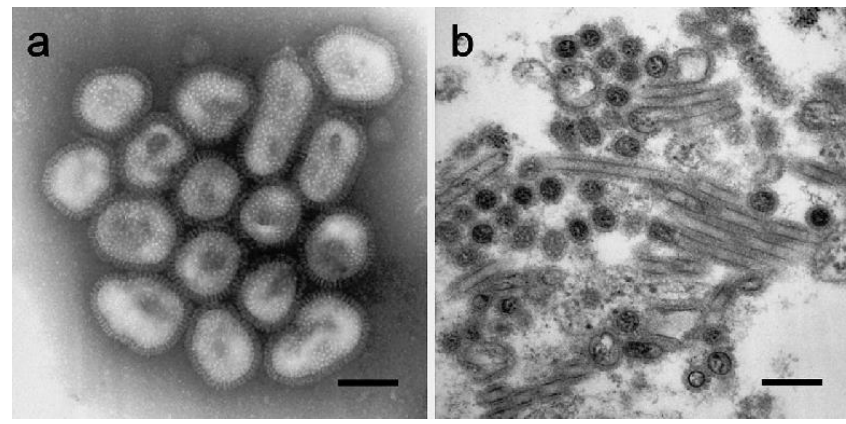

Figure 2. Electron microscopy of isolated influenza (A/H1N1pdm) virus particles in the culture supernatant (a) and (b) in filamentous forms in the lung sections (Nakajima et al., 2010).

Human influenza viruses mainly reproduce in the respiratory tract, but avian variants predominantly exist in the bird gastrointestinal tract. This means that the viruses are excreted with a large number of feces in dense waterfowl populations. Consequently, water is considered to be an essential element in the natural transfer of avian influenza viruses among populations of wild birds through an indirect fecal-oral way involving fecal polluted water in shared aquatic habitats (Bosch, 2007; Brown et al., 2009; Grabow, 2007; Markwell, 1982; Nazir et al., 2011; Root, 2014; Sandu \& Hinshaw, 1981). There are two major routes of AIV transmission: (i) a direct bird-to-bird transmission and (ii) a waterborne transmission. Researches have shown that waterborne transmission is an effective way of distributing and transmitting the avian influenza virus (Dovas et al., 2010; Roche et al., 2009; Thanapongtharm et al., 2013). This transfer process is highly effective since it persists in water for long periods within such temperature ranges (Brown et al., 2009; Domanska-Blicharz et al., 2010; Stallknecht et al., 1990; Webster et al., 1978). Studies have shown that the H5N1 and H9N2 viruses can live longer with appropriate water conditions, including $\mathrm{pH}$, salinity, and cold, for up to several months (Brown et al., 2009; Liu et al., 2005; Zhang, 2014). Dublineau et al., (2011) observed that the pandemic influenza virus can survive infectious as a minimum of 200 days at $4^{\circ} \mathrm{C}$ in water.

The varied biotic water ecosystems, including fish and shellfish, are also susceptible to a variety of contaminants being discharged into the marine environments. Shellfish as filter feeders appear to 
bioconcentrate the virus in the contaminated aquatic environments (Huyvaert et al., 2012) and serve as effective vessels for their spread (Lees, 2000; Skraber et al., 2005). Firstly, Scholtissek and Naylor, (1988) illustrated the expected function of combined culture by fish and ducks as fertilizer for fish farming systems in influenza pandemic transmission. Pathak et al., (2018) demonstrated that under laboratory conditions, bamboo shrimps (Atyopsis moluccensis), which are essential members of aquatic fauna for the reason that large fish, birds and humans eat them (Chace, 1983), may absorb the virus and stay infectious throughout the shrimp body. Huyvaert et al., (2012) has also reported that freshwater clams (Corbicula fluminea) can accumulate avian influenza and an important resource for early detection of H1N1 viruses in the marine environment. Eissa et al., (2012) documented that several aquatic species have a vital role in providing an intermediate path for the transmission, distribution, and dissemination of influenza viruses to and from susceptible marine and poultry populations with a two-year analysis in maritime and freshwater regions in Egypt from the neighborhood of natural migratory bird stop stations. They also detected avian influenza (H5N1) in Red Swamp Crayfish (Procambarus clarkii), Catfish (Clarias gariepinus), Puffer Fish (Lagocephalus sceleratus) and Mediterranean Cone Shell (Conus mediterraneus) in Egypt from the neighborhood of natural stopping stations for migratory birds. Densmore et al., (2019) is the first to confirm influenza A virus infection from a natural water source in clam and mussel tissue. Likewise, Stumpf et al., (2010) found that influenza A viruses were collected by zebra mussels ( $D$. polymorpha) from topsoil, and that such viruses persist in the mussels for prolonged periods.

\section{CORONAVIRUSES}

Severe acute respiratory syndrome (SARS-CoV): A serious acute respiratory syndrome (SARS-CoV), which occurred in 2781 cases with 111 deaths recorded on 10 April 2003 from 17 countries on 3 continents, is both an enteric and respiratory disorder (Nwachcuku \& Gerba, 2004). SARS-CoV was phylogenetically distinct from all human and animal coronaviruses previously recognized (Weber et al., 2016). Figure 3 shows the ultrastructural appearances of SARS-CoV developed in Vero e6 cells (Ksiazek et al., 2003).

Because the virus is excreted in respiratory secretions, the feces often excrete significant numbers; as many as 1,31107 viruses per gram of feces. Studies have demonstrated that SARS-CoV can survive in stool samples at room temperature for 4 days (Nwachcuku \& Gerba, 2004; Wang et al., 2005; Weber et al., 2016). Infected stools in wastewater may create additional spread routes by creating virus-laden aerosols throughout wastewater flushing (Isakbaeva et al., 2004; Qu et al., 2020). Peiris et al., (2003) reported that epidemiological investigations of 321 patients who were associated with coronavirus- SARS outbreak in a high-rise residential estate in Hong Kong (March 24 in 2003) could be related to a defective sewage system. Several reports have recorded that coronavirus stays transmissible in water and wastewater for days to weeks (Casanova et al., 2009; McKinney et al., 2006; Nwachcuku \& Gerba, 2004). Scientists recorded that it took many days to reduce virus infectivity by $99 \%$ at room temperature, in liquid water or pasteurized settled sewage. SARS-CoV was observed at $20{ }^{\circ} \mathrm{C}$ for 2 days in hospital sewage, domestic wastewater and tap water and at $4{ }^{\circ} \mathrm{C}$ for up to 14 days (Pinon \& Vialette, 2018), at least 17 days in fecal or urine (Wang et al., 2005), thereby demonstrating a clear temperature effect on viral persistence (La Rosa et al., 2020a; Leung et al., 2003). Two surrogate coronaviruses were tested by Casanova et al., (2009) and they noticed that this transmissible gastroenteritis (TGEV) and mouse hepatitis (MHV) viruses in pasteurized settled sewage stayed contagious for days to weeks. At $25{ }^{\circ} \mathrm{C}$, it took 22 days for TGEV to minimize reagent-grade water by $99 \%$ and 17 days for MHV. The period for a 99 percent drop of pasteurized settled waste was 7 days for MHV, and 9 days for TGEV.
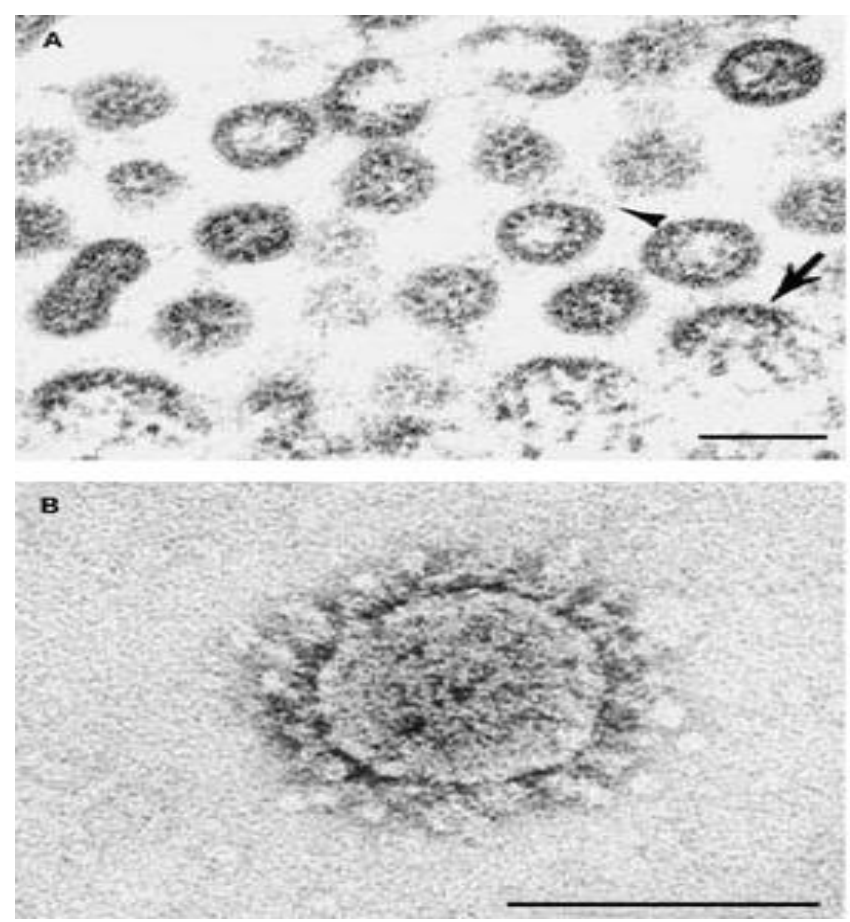

Figure 3. Ultrastructural Appearances Of SARS-CoV Developed In Vero E6 Cells (Ksiazek et al., 2003).

In marine environments, the rate of virus decay can be significantly affected by the viral genome and envelope properties; thus, coronaviruses are believed to have characteristics of survival and disinfection that vary 
from smaller and non-enveloped viruses (Silverman \& Boehm, 2020; Wigginton et al., 2015). Enveloped viruses are usually deemed inconsistent in aquatic life and thus have not been stressed in studies, procedures, or regulations on waterborne viruses. The waterborne infection has never been seen in humans, but identification of human coronavirus $(\mathrm{HCoV})$ and SARS-CoV in the feces of infected patients was documented (Drosten et al., 2003; Esper et al., 2010; Vabret et al., 2006), indicating that the fecal-oral way can cause $\mathrm{HCoV}$ (La Rosa et al., 2020b) and SARS-CoV transmission. Nevertheless, certain enveloped viruses may live in soil and surface waters such as influenza A for long times. For example, certain coronaviruses are comparatively stable in aquatic life and can even spread to humans and cause serious outbreaks. The virus is similar to coronaviruses, which are known as part of the intestinal viral flora of a lot of people and were identified in the feces of patients and wastewater and were found to survive for a long time at low temperature (Leung et al., 2003; Wang et al., 2005; Ye et al., 2016). It was thought necessary to link waterborne infection with influenza virus, all of which have a typical envelope (Gundy et al., 2009; Peiris et al., 2003; Wigginton et al., 2015). However, there is a deficiency in the studies about waterborne transmission as with the avian influenza viruses. Consequently, the increased possibility of respiratory virus infections such as influenza and SARS especially in aquatic environments can not be overlooked for filter filtering shellfish and fish farming/catching in uncontrolled sewage and wastewater regions to protect human health against coronavirus through water (Todd \& Grieg, 2015).

SARS-CoV, as well as monkeypox (Rimoin et al., 2010) and Nipah virus (Luby et al., 2009), can be transmitted via food-related occurrences, either by zoonotic food consumption or during food handlers and food production if the personal hygiene quality is poor (Bell et al., 2004; Bosch et al., 2016; Leung et al., 2006; Koopmans, 2012; Qu et al., 2020; Shao et al., 2011; Todd \& Grieg, 2015). Mullis et al., (2012) studied the stability of coronaviruses on the lettuce surface by using $\mathrm{BCoV}$ as a surrogate of the Genus Betacoronavirus, which contains SARS-CoV, under household refrigeration conditions. They observed that lettuce $\mathrm{BCoV}$ maintained infectivity at $4^{\circ} \mathrm{C}$ for at least 14 days, and higher infectious particle amounts. They also saw that the coronavirus remained stable throughout the shelf-life of the lettuce, and caused a washing process (elution) to no longer eliminate the residual viruses. UV lights, thermal exposure $\left(\geq 65^{\circ} \mathrm{C}\right)$, acidic $\mathrm{pH}(<3)$, or alkaline $\mathrm{pH}(>12)$ milieu could inactivate SARS-CoV (Darnell et al., 2004). It is suggested that SARS-CoV, even though it is mainly spread through droplets and direct contacts, should not be ignored for potential environmental transmission via water, bioaerosols, and food (Annaloura et al., 2020).

Severe acute respiratory syndrome coronavirus 2 (SARS CoV-2): SARS-CoV-2 is an enveloped RNA virüs single-stranded as a genetic material having the size of $29.9 \mathrm{~kb}$ with a particle size of $100-160 \mathrm{~nm}$ in diameter, the largest among all the RNA viruses (Zehra et al., 2020). It contains four structural proteins, titled the $\mathrm{S}$ (spike), $\mathrm{E}$ (envelope), M (membrane), and $\mathrm{N}$ (nucleocapsid) proteins and belongs to beta-coronavirus (Liya et al., 2020). Transmission electron microscopy images of SARS-CoV2 grown in the Vero cell line are given in Figure 4 (Taştan et al., 2020).

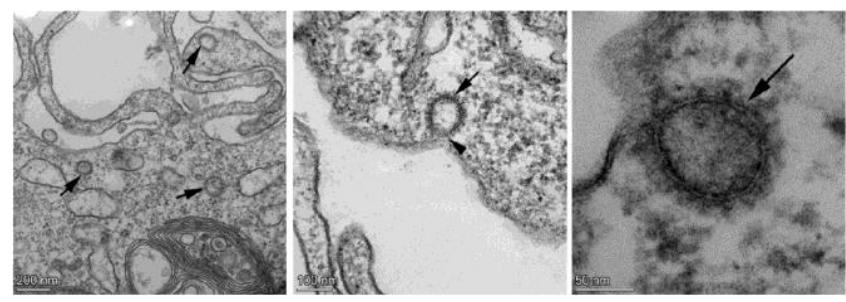

Figure 4. Transmission electron microscopy images of SARSCoV-2 grown in Vero cell line (Taştan et al., 2020).

SARS-CoV-2 is the main reason for the global pandemic of Severe Acute Respiratory Syndrome, resulting in infections and death of millions worldwide with high variability in cases and mortality. On 11 March 2020, the WHO stated that Covid-19 was a pandemic on the grounds of "threatening rates of spread and magnitude, and threatening rates of inaction" (Medema et al., 2020). As of that date, it has already spread to more than 219 countries in the world surpassing more than 2 million deaths and nearly 96 million reported active cases worldwide (https://www.worldometers.info/coronavirus/).

Water-borne Transmission: SARS-CoV-2 is spread mainly by respiratory droplets from an infected individual to a susceptible host (Walker et al., 2020; Lai et al., 2020). At the present, various researchers have reported the infectious SARS-CoV-2 in the feces and urine of infected patients (Chen et al., 2020a; Elsamadony et al., 2021; Xiao et al., 2020 a,b). It is also reported by Wu et al., (2020a) who suggest that fecal-oral transmission could occur after viral clearance in the respiratory tract. Zheng et al., (2020) evaluated SARS-CoV-2 dynamics in China's Zhejiang province and they found the longer mean duration of SARS-CoV-2 in the stool samples (22 days, H-spread 17-31 days) than those in respiratory airways (18 days) and serum (16 days) samples. Several experiments in marine and drainage ecosystems around the world have observed signs of SARS-CoV-2 RNA (Ahmed et al., 2020; D'Aoust et al., 2021; Eslami \& Jalili 2020; Lodder \& de Roda Husman, 2020; Orive et al., 2020; Peccia et al., 2020; Wu et al., 2020b; Wurtzer et al., 2020). Randazzo et al., (2020) detected SARS-CoV-2 RNA in six wastewater 
treatment plants in the main metropolises within the Province of Murcia (Spain), the lowest COVID-19 prevalence in the Iberian Peninsula. For the first time, Guerrero-Latorre et al., (2020) identified significant viral loads of SARS-CoV-2 from rivers in 180 urban streams of Quito, where insufficiently handled sewage discharges on June 5 during a COVID-19 season. They also reported that the amount usually removed $\left(6-7 \log _{10}\right)$ through the recycled water disinfection methods is much lower than viral particles shedding (up to $10 \log _{10}$ ) by infected people through sewage and greywater. Many researchers have been thought that these results showed an increased potential of contamination through the fecal-oral infection route from the water environment (Bhattacharjee, 2020; Chen et al., 2020b; Holshue et al., 2020; Medema et al., 2020; Oliver et al., 2020; Qu et al., 2020; Xiao et al., 2020a,b).

Water-borne human pathogenic viruses related to seafood are primarily spread via fecal-oral way due to feeding habits and their pre-harvest growing area, particularly where may contaminate the virus concerning the inadequate or raw discharge of feces or sewage in water bodies (Bosch et al., 2005; Butt et al., 2004; Gerba 2007; Grabow, 2007; Li et al., 2021). Although enveloped viruses were found to be degrading in water compared to nonenveloped viruses (Gundy et al., 2009; Lebarbenchon et al., 2011), studies have shown that seafood can accumulate enveloped viruses such as avian influenza (Densmore et al., 2019; Eissa et al., 2012; Huyvaert et al., 2012; Pathak et al., 2018). The structure of avian influenza, as well as the other enveloped viruses such as H1N1 "Spanish flu,", SARS-CoV, MERS-CoV found in the stools and urine of infected human samples are similar to coronaviruses (Wigginton et al., 2015). Annalaura et al., (2020) detected the longer survival of SARS-CoV-2 in vitro experiments at low temperatures and they recommend that SARSCoV-2 excreted in feces may enter infectious wastewater treatment plants particularly in cool climates. Furthermore, the existence of fecally infected food is supposed to be a significant role in coronavirus transmission by scientists (Baduashvili et al., 2020; El Baz \&Imziln, 2020; Li et al., 2021; Mullis et al., 2012; Tian et al., 2020; Zhang et al., 2020). Although, these concerns, even if there are no cases of waterborne transmission via fecal-oral route, have thought to be the importance of the possible waterborne transmission via fecal-oral route for SARS-CoV-2 (Ghernaout \&Ghernaout, 2020; Heller et al., 2020; Qu et al., 2020; Rizou et al., 2020; WHO, 2019; Yeo et al., 2020), the current existence of it in feces and urine of infected people and its accelerated dissemination requires new attention to detect it in aquatic environment wşth respect to the existence of the virus and its possible infectivity. However, the current evidence shows that the possible water-borne transmission of SARS-CoV-2 may be very low.

Food-borne Transmission: SARS-CoV-2 can be transmitted as a widely agreed mode of transmission for respiratory diseases by either touching a polluted surface or object and consequently infecting itself through oral, nasal or optical routes eyes (BFR, 2020; Dawson, 2020; Lei et al., 2020; Pressman et al., 2020; Shahbaz et al., 2020) or intake of infected food (Dawson, 2020). According to WHO, SARS-CoV-2 can spread through hands, sneezing and coughing of infected workers responsible for the preparation and packaging of foods (WHO, 2020).

Previous studies have shown that coronavirus stability is mostly dependent on the ambient temperature (Ijaz et al., 1985; Mullis et al., 2012; Siddell et al., 1983; Tennant et al., 1994). In a study conducted as a surrogate of bovine coronavirus Genus Betacoronavirus, it was shown that it survived on lettuce for up to two days at environmental temperature and at least 14 days at $4^{\circ} \mathrm{C}$ (Mullis et al., 2012). Van Doremalen et al., (2014) found that MERS-CoV can live at various temperatures for long periods, when it is injected into dromedary camel milk, goat milk, and cow milk. Nipah virus has been experimentally transmitted by liquids, causing a respiratory tract infection rather than intestinal tract infection (de Wit et al., 2014).

A new study showed that SARS-CoV-2 could stay viable in the environment for up to 3 hours, on copper for up to 4 hours, on carton for up to 24 hours and on plastic and stainless steel for up to 72 hours (Van Doremalen et al., 2020). In fact, SARS-CoV-2 experiments have shown that the virus is extremely stable at $4^{\circ} \mathrm{C}$ and WHO (2020) suggests that it may stay infectious at $-20^{\circ} \mathrm{C}$ for a long time (up to 2 years) The survival of SARS-CoV-2 in salmon meat at cold storage $\left(+4^{\circ} \mathrm{C}\right)$ by using end-point titration assay on Vero E132 cells has been shown by Dai et al. (2020). They found that salmon-attached SARS-CoV-2 ability remained infectious for more 24 than one week at $4^{\circ} \mathrm{C}$. According to their results, they suggested that because seafood should be transported for import and export with cold storage (e.g., $0 \sim 4^{\circ} \mathrm{C}$ ), SARS-CoV-2 for international transmission can be easily carry-through contaminated seafood within one week. Pung et al., (2020) pointed out that a cluster of COVID-19 patients in Singapore shared food and social interaction in a conference was caused. Yekta et al., (2020) also reported that there is some evidence that the transmission of SARS-CoV-2 may be possible through meat products. $\mathrm{Li}$ et al. (2021) also suggest that $\mathrm{CoVs}$ as well as norovirus (NoVs) known to be the primary causative agent of seafood transmitted illness (Bachofen 2018; Li et al. 2014), may be transmitted especially at low temperatures due to having enough time for remaining infectious on foods and/or food packaging 
materials. Similar suggestions have also been made by other researchers (Rizou et al., (2020) for frozen or cold stored foods.

Although no research studies have been conducted to examine the stability of SARS-CoV-2 on packaging under real-world conditions and through the supply chain, the findings of this study pose concerns that packaging may play an important role in helping to spread the virus, particularly at low temperatures (Boucher, 2020; Li et al., 2021). Consequently, as recommended by the WHO and regional health authorities, the Food Packaging Forum suggests that consumers pay regard to either (i) washing all the packages right away with soap and water or cleaning them with disinfectant directly when it gets in the house with soap and water, (ii) alternatively, unpacking the packaged things and then transferring them to clean pots to store them, and then tossing the packaging out, or (iii) quarantining the household items for three days in before they are touched again. Such guidelines refer to products bought in shops and brought to households, such as mail order grocery stores or meal delivery, etc. (Boucher, 2020). Seymour et al., (2020) suggested that washing hands or using hand sanitizer and disinfecting products should be done before carrying or touching packages to reduce the risk of potentially being exposed to coronavirus. Moreover, proper sanitation measures, as well as washing and sanitizing the surfaces of the kitchens and restaurants, are preferable safeguards compared to environmental surveillance of SARS-CoV-2 (FDA, 2020).

Moreover, proper cooking of seafood seems to be enough for safe consumption of them. Chin et al., (2020) observed that SARS-CoV-2 was inactivated after 5 minutes of incubation at $70^{\circ} \mathrm{C}$. Such results reinforce the value of cooking or preparing food at $70^{\circ} \mathrm{C}$ for at least 5 minutes to reduce the possibility of transmission of SARSCoV-2 via a possibly infected food supply. Shahidi (2020) suggests that consumption of all cooked food should be safe because no viable viruses can be identified after heat treatment. Until now, there were no records of COVID-19 being spread by seafood as well as other foods.

\section{CONCLUSION}

Nowadays, people go through an unprecedented, huge challenge and disaster all over the world because of the SARS-CoV-2 outbreak. Many scientific evidences indicate that the aquatic environments may contain both RNA fragments and viable viruses. Moreover, in-vitro experiments have been shown that SARS-CoV-2 may survive at low temperatures and the potentials to stay infectious on foods and/or food packaging materials long enough to potentially cause transmission. Low temperature preservation of seafood during processing, storage, transfer, distribution and display in retail stores are common methods. With this perspective, it seems that SARS-CoV-2 can survive on seafood and their environmental surface and fomites. However, there is no scientific evidence on waterborne or foodborne transmission of SARS-CoV-2. So, the chance of either waterborne or foodborne transmission of it is considered low and SARS-CoV-2 appears to mainly be spread through the respiratory tract. Consequently, seafood can safely consume with proper cooking and hygiene protocol.

\section{ACKNOWLEDGEMENTS}

The icons and vectors used in the graphical abstract were taken from https://www.freepik.com and some of them are modified.

\section{REFERENCES}

Ahmed, W., Angel, N., Edson, J., Bibby, K., Bivins, A., O'Brien, J.W., ... \& Tscharke, B. (2020). First confirmed detection of SARS-CoV-2 in untreated wastewater in Australia: A proof of concept for the wastewater surveillance of COVID-19 in the community. Science of The Total Environment, 738, 138764. DOI: $10.1016 /$ j.scitotenv.2020.138764

Annalaura, C., Ileana, F., Dasheng, L. \& Marco, V. (2020). Making waves: Coronavirus detection, presence and persistence in the water environment: State of the art and knowledge needs for public health. Water Research, 115907.

Bachofen, C. (2018). Selected viruses detected on and in our food. Current Clinical Microbiology Reports, 5(2), 143-153.

Baduashvili, A., Oberle, L.P. \& Devitt, J. (2020). Frequency of Continuous Renal Replacement Therapy Use Early in Coronavirus Disease 2019 Pandemic. Critical Care Explorations, 2(5), 0129.

Bell, D., Roberton, S. \& Hunter, P.R. (2004). Animal origins of SARS coronavirus: possible links with the international trade in small carnivores. Philosophical Transactions of the Royal Society of London. Series B: Biological Sciences, 359(1447), 1107-1114.

BFR. (2020). Can the new type of coronavirus be transmitted via food and objects? - BFR. https://www.bfr.bund.de/en/can_the_new_type_of_ coronavirus_be_transmitted_via_ food_and_objects_-244090.html

Bhattacharjee, S. (2020). Statistical investigation of relationship between spread of coronavirus disease (COVID-19) and environmental factors based on study of four mostly affected places of China and five mostly affected places of Italy. https://arxiv.org/ftp/arxiv/papers/2003/2003.11277. pdf.

Bosch, A. (2007). Human Viruses in Water. Elsevier Academic Press, Amsterdam, The Netherlands

Bosch, A., Abad, F.X. \& Pintó, R.M. (2005). Human pathogenic viruses in the marine environment. In 
Oceans and health: pathogens in the marine environment (pp. 109-131). Springer, Boston, MA.

Botero, L., Montiel, M. \& Porto, L. (1996). Enteroviruses in shrimp harvested from contaminated marine waters. International Journal of Environmental Health Research, 6(2), 103-108.

Boucher, R.C. (2020). A College Senior in the Time of Coronavirus. Vanderbilt Lives, 3.

Brown, J.D., Goekjian, G., Poulson, R., Valeika, S. \& Stallknecht, D.E. (2009). Avian influenza virus in water: infectivity is dependent on $\mathrm{pH}$, salinity and temperature. Veterinary Microbiology, 136(1-2), 2026.

Casanova, L., Rutala, W.A., Weber, D.J. \& Sobsey, M.D. (2009). Survival of surrogate coronaviruses in water. Water Research, 43(7), 1893-1898.

Chace, F.A.J.R. (1983). The Atya-like shrimp of the IndoPacific region (Decapoda: Atyidae). Smithsonian Contributions to Zoology, 384, 1-54.

Chen, N., Zhou, M., Dong, X., Qu, J., Gong, F., Han, Y., ... \& Yu, T. (2020b). Epidemiological and clinical characteristics of 99 cases of 2019 novel coronavirus pneumonia in Wuhan, China: a descriptive study. The Lancet, 395(10223), 507-513.

Chen, Y., Chen, L., Deng, Q., Zhang, G., Wu, K., Ni, L., ... \& Cheng, Z. (2020a). The presence of SARS-CoV2 RNA in the feces of COVID-19 patients. Journal of Medical Virology, 92, 833-84.

Cheng, P.K., Wong, D.K., Chung, T.W. \& Lim, W.W. (2005). Norovirus contamination found in oysters worldwide. Journal of Medical Virology, 76(4), 593597.

Chin, A., Chu, J., Perera, M., Hui, K., Yen, H. L., Chan, M., ... \& Poon, L. (2020). Stability of SARS-CoV2 in different environmental conditions. medRxiv. DOI: 10.1101/2020.03.15.20036673

Cui, J., Li, F. \&. Shi, Z.L. (2019). Origin and evolution of pathogenic coronaviruses. Nature Reviews Microbiology, 17(3), 181-192.

Dai, M., Li, H., Yan, N., Huang, J., Zhao, L., Xu, S., ... \& Liao, M. (2020). Long-term survival of salmonattached SARS-CoV-2 at $4^{\circ} \mathrm{C}$ as a potential source of transmission in seafood markets. bioRxiv. DOI: 10.1101/2020.09.06.284695

Darnell, M.E., Subbarao, K., Feinstone, S.M. \& Taylor, D.R. (2004). Inactivation of the coronavirus that induces severe acute respiratory syndrome, SARSCoV. Journal of Virological Methods, 121(1), 8591.

Dawson, P. (2020). Transfer of microorganisms and respiratory viruses through food. Medical Research Archives, 8(5), 1-17. DOI: 10.18103/mra.v8i5

de Wit, E., Prescott, J., Falzarano, D., Bushmaker, T., Scott, D., Feldmann, H. \& Munster, V.J. (2014). Foodborne transmission of nipah virus in Syrian hamsters. PLoS Pathog, 10(3), e1004001.

Densmore, C.L., Iwanowicz, D.D., McLaughlin, S.M., Ottinger, C.A., Spires, J.E. \& Iwanowicz, L.R. (2019). Influenza A Virus Detected in Native Bivalves in Waterfowl Habitat of the Delmarva Peninsula, USA. Microorganisms, 7(9), 334.

Domanska-Blicharz, K., Minta, Z., Smietanka, K., Marché, S. \& Van Den Berg, T. (2010). H5N1 high pathogenicity avian influenza virus survival in different types of water. Avian Diseases, 54(1), 734737.

Dovas, C.I., Papanastassopoulou, M., Georgiadis, M.P., Chatzinasiou, E., Maliogka, V.I. \& Georgiades, G.K. (2010). Detection and quantification of infectious avian influenza A (H5N1) virus in environmental water by using real-time reverse transcription-PCR. Applied and Environmental Microbiology, 76(7), 2165-2174.

Drosten, C., Günther, S., Preiser, W., Van Der Werf, S., Brodt, H. R., Becker, S., ... \& Doerr, H. W. (2003). Identification of a novel coronavirus in patients with severe acute respiratory syndrome. New England journal of medicine, 348(20), 1967-1976.

Dublineau, A., Batéjat, C., Pinon, A., Burguière, A.M. \& Manuguerra, J.C. (2011). Persistence of the 2009 pandemic influenza A (H1N1) virus in water and on non-porous surface. PLoS One, 6(11), e28043.

Eissa, A.E., Hussein, H.A. \& Zaki, M.M. (2012). Detection of avian influenza (H5N1) in some fish and shellfish from different aquatic habitats across some Egyptian provinces. Life Science Journal, 9(3), 2702-2712.

EI Baz, S. \& Imziln, B. (2020). Can human transmit COVID19 to animal? Journal of Clinical \& Experimental Investigations/Klinik ve Deneysel Arastirmalar Dergisi, 11(3),1-3

Elsamadony, M., Fujii, M., Miura, T. \& Watanabe, T. (2021). Possible transmission of viruses from contaminated human feces and sewage: Implications for SARS-CoV-2. Science of The Total Environment, $755,142575$.

Eslami, H. \& Jalili, M. (2020). The role of environmental factors to transmission of SARS-CoV-2 (COVID19). AMB Express, 10(1), 1-8.

Esper, F., Ou, Z. \& Huang, Y.T. (2010). Human coronaviruses are uncommon in patients with gastrointestinal illness. Journal of Clinical Virology, 48(2), 131-133.

FDA. (2020). Best practices for retail food stores, restaurants, and food pick-up/delivery services during the COVID-19 pandemic | FDA. https://www.fda.gov/food/foodsafety-duringemergencies/best-practices-retail-food-storesrestaurants-and-foodpick-updelivery-servicesduring-covid-19.

Ghernaout, D. \& Ghernaout, B. (2020). Controlling COVID-19 pandemic through wastewater monitoring. Open Access Library Journal, 7(5), 1 20.

Gibson, K.E. (2014). Viral pathogens in water: occurrence, public health impact, and available control strategies. Current Opinion n Virology, 4, 50-57.

Goyal, S.M. \& Nelson, M.D. (1984). Viral pollution of the marine environment. Critical Reviews in Environmental Control, 14(1), 1-32.

Griffin, D.W., Donaldson, K.A., Paul, J.H. \& Rose, J.B. (2003). Pathogenic human viruses in coastal waters. Clinical Microbiology Reviews, 16(1), 129-143.

Guerrero-Latorre, L., Ballesteros, I., Villacres, I., Granda-Albuja, M.G., Freire, B. \& Rios-Touma, B. (2020). First SARS-CoV-2 detection in river water: implications in low sanitation countries. medRxiv. DOI: 10.1101/2020.06.14.20131201 
Gundy, P.M., Gerba, C.P. \& Pepper, I.L. (2009). Survival of coronaviruses in water and wastewater. Food and Environmental Virology, 1(1), 10.

Hejkal, T.W. \& Gerba, C.P. (1981). Uptake and survival of enteric viruses in the blue crab, Callinectes sapidus. Applied and Environmental Microbiology, 41(1), 207-211.

Heller, L., Mota, C.R. \& Greco, D.B. (2020). COVID-19 faecal-oral transmission: Are we asking the right questions? Science of the Total Environment, 138919.

Holshue, M.L., DeBolt, C., Lindquist, S., Lofy, K.H., Wiesman, J., Bruce, H., ... \& Pillai, S. (2020). First case of 2019 novel coronavirus in the United States. New England Journal of Medicine, 382, 929-936.

Hussain, M.M., Islam, M.S., Al Mahmud, M.A., Islam, M.N. \& Hasan, K. (2016). Prevalence of avian influenza in three selected upazilas of Barisal district in Bangladesh. International Journal of Natural and Social Sciences, 3(2), 01-03.

Huyvaert, K.P., Carlson, J.S., Bentler, K.T., Cobble, K.R., Nolte, D.L. \& Franklin, A.B. (2012). Freshwater clams as bioconcentrators of avian influenza virus in water. Vector-Borne and Zoonotic Diseases, 12(10), 904-906.

Ijaz, M.K., Brunner, A.H., Sattar, S.A., Nair, R.C. \& Johnson-Lussenburg, C.M. (1985). Survival characteristics of airborne human coronavirus 229E Journal of General Virology, 66(12), 2743-2748.

Isakbaeva, E.T., Khetsuriani, N., Beard, R.S., Peck, A., Erdman, D., Monroe, S.S., ... \& SARS Investigation Group. (2004). SARS-associated coronavirus transmission, United States. Emerging Infectious Diseases, 10(2), 225.

Kampf, G., Todt, D., Pfaender, S. \& Steinmann, E. (2020). Persistence of coronaviruses on inanimate surfaces and their inactivation with biocidal agents. Journal of Hospital Infection, 104(3), 246-251.

Koopmans, M. \& Duizer, E. (2004). Foodborne viruses: an emerging problem. International Journal of Food Microbiology, 90(1), 23-41.

Koopmans, M. (2005). Food-borne norovirus outbreaks: a nuisance or more than that? Wien Klin Wochenschr, 117, 789-791

Kovač, K., Gutiérrez-Aguirre, I., Banjac, M., Peterka, M., Poljšak-Prijatelj, M., Ravnikar, M., ... \& Raspor, P. (2009). A novel method for concentrating hepatitis A virus and caliciviruses from bottled water. Journal of Virological Methods, 162(1-2), 272-275.

Ksiazek, T. G., Erdman, D., Goldsmith, C. S., Zaki, S. R., Peret, T., Emery, S., ... \& SARS Working Group. (2003). A novel coronavirus associated with severe acute respiratory syndrome. New England Journal of Medicine, 348(20), 1953-1966.

La Rosa, G., Bonadonna, L., Lucentini, L., Kenmoe, S. \& Suffredini, E. (2020a). Coronavirus in water environments: Occurrence, persistence and concentration methods-A scoping review. Water Research, 115899.

La Rosa, G., Iaconelli, M., Mancini, P., Ferraro, G.B., Veneri, C., Bonadonna, L., Lucentini, L., ... \& Suffredini, E. (2020b). First detection of SARSCoV-2 in untreated wastewaters in Italy. Science of the Total Environment, 736, 139652. DOI: 10.1016/j.scitotenv.2020.139652

La Rosa, G., Mancini, P., Ferraro, G.B., Veneri, C., Iaconelli, M., Bonadonna, L., Lucentini, L., ... \& Suffredini, E. (2020c). SARS-CoV-2 has been circulating in northern Italy since December 2019: evidence from environmental monitoring. Science of The Total Environment, 750, 141711. DOI: 10.1016/j.scitotenv.2020.141711

Lai, C.C., Shih, T.P., Ko, W.C., Tang, H.J. \& Hsueh, P.R. (2020). Severe acute respiratory syndrome coronavirus 2 (SARS-CoV-2) and corona virus disease-2019 (COVID-19): the epidemic and the challenges. International Journal of Antimicrobial Agents, 55, 105924.

Lebarbenchon, C., Yang, M., Keeler, S.P., Ramakrishnan, M.A., Brown, J.D., Stallknecht, D.E. \& Sreevatsan, S. (2011). Viral replication, persistence in water and genetic characterization of two influenza A viruses isolated from surface lake water. PloS one, 6(10), e26566. DOI: 10.1371/journal.pone.0026566

Lees, D. (2000). Viruses and bivalve shellfish. International Journal of Food Microbiology, 59(1-2), 81-116.

Lei, H., Xiao, S., Cowling, B.J. \& Li, Y. (2020). Hand hygiene and surface cleaning should be paired for prevention of fomite transmission. Indoor Air, 30(1), 49-59.

Leung, G.M., Lim, W.W., Ho, L.M., Lam, T.H., Ghani, A.C., Donnelly, C.A., ... \& Hedley, A.J. (2006). Seroprevalence of $\mathrm{IgG}$ antibodies to SARScoronavirus in asymptomatic or subclinical population groups. Epidemiology \& Infection, 134(2), 211-221. DOI: $10.1017 / \mathrm{S} 0950268805004826$

Leung, W.K., To, K.F., Chan, P.K., Chan, H.L., Wu, A.K., Lee, N., ... \& Sung, J.J. (2003). Enteric involvement of severe acute respiratory syndrome-associated coronavirus infection. Gastroenterology, 125(4), 1011-1017.

Li, D., Stals, A., Tang, Q.J. \& Uyttendaele, M. (2014). Detection of noroviruses in shellfish and semiprocessed fishery products from a Belgian seafood company. Journal of Food Protection, 77(8), 1342-1347.

Li, D., Zhao, M.Y. \& Hsern, M.T.T. (2021). What makes a foodborne virus: comparison between coronaviruses with human noroviruses. Current Opinion in Food Science, 42,1-7

Liu, J., Xiao, H., Lei, F., Zhu, Q., Qin, K., Zhang, X.W., ... \& Gao, G.F. (2005). Highly pathogenic H5N1 influenza virus infection in migratory birds. Science, 309(5738), 1206-1206.

Liya, G., Yuguang, W., Jian, L., Huaiping, Y., Xue, H., Jianwei, H., ... \& Yiqing, J. (2020). Studies on viral pneumonia related to novel coronavirus SARS-CoV2, SARS-CoV, and MERS-CoV: a literature review. APMIS, 128(6), 423-432.

Lodder, W. \& de Roda Husman, A.M. (2020). SARS-CoV2 in wastewater: potential health risk, but also data source. The Lancet Gastroenterology \& Hepatology, 5(6), 533-534.

Luby, S.P., Nahar, N. \& Gurley, E.S. (2016). Reducing the risk of foodborne transmission of Nipah virus. In 
Food Safety Risks from Wildlife (pp. 151-167). Springer, Cham.

Markwell, D.D. \& Shortridge, K.F. (1982). Possible waterborne transmission and maintenance of influenza viruses in domestic ducks. Applied and Environmental Microbiology, 43(1), 110-115.

McKinney, K.R., Gong, Y.Y. \& Lewis, T.G. (2006). Environmental transmission of SARS at Amoy Gardens. Journal of Environmental Health, 68(9), 26.

Medema, G., Heijnen, L., Elsinga, G., Italiaander, R. \& Brouwer, A. (2020). Presence of SARS Coronavirus-2 in sewage. Environmental Science \& Technology Letters, 7(7), 511-516. DOI: 10.1101/2020.03.29.20045880

Mullis, L., Saif, L.J., Zhang, Y., Zhang, X. \& Azevedo, M.S. (2012). Stability of bovine coronavirus on lettuce surfaces under household refrigeration conditions. Food Microbiology, 30(1), 180-186.

Nakajima, N., Hata, S., Sato, Y., Tobiume, M., Katano, H., Kaneko, K., ... \& Sata, T. (2010). The first autopsy case of pandemic influenza $(\mathrm{A} / \mathrm{H} 1 \mathrm{~N} 1 \mathrm{pdm})$ virus infection in Japan: detection of a high copy number of the virus in type II alveolar epithelial cells by pathological and virological examination. Japanese Journal of Infectious Diseases, 63(1), 67-71.

Nazir, J., Haumacher, R., Ike, A.C. \& Marschang, R.E. (2011). Persistence of avian influenza viruses in lake sediment, duck feces, and duck meat. Applied and Environmental Microbiology, 77(14), 4981-4985.

Nwachcuku, N. \& Gerba, C.P. (2004). Emerging waterborne pathogens: can we kill them all? Current Opinion in Biotechnology, 15(3), 175-180.

Ohimain, E.I. (2016). Ecology of Ebolavirus: a Review of Current Knowledge, Speculations and Future Research Directions. Virology, 1(3), 555564.

OIE (Office International des Epizooties). (2019). WAHIS country report, Namibia. http://www. oie.int/wahis_2/public/wahid.php/

Countryinformation/Countryreports. Accessed May 2019

Oliver, M.M.H., Hewa, G.A., Pezzaniti, D., Haque, M.A., Haque, S., Haque, M.M., ... \& Kadir, M.N. (2020). COVID-19 and Recycled Wastewater Irrigation: A Review of Implications. Preprints, DOI: 10.20944/preprints202006.0105.v1

Orive, G., Lertxundi, U. \& Barcelo, D. (2020). Early SARSCoV-2 outbreak detection by sewage-based epidemiology. Science of the Total Environment, 732, 139298.

Palese, P. \& Shaw, M.L. (2007). Orthomyxoviridae: The Viruses and Their Replication, 404 p. Fields Virology, Fifth Edition ed, 2, 405.

Pathak, A.P., Murugkar, H.V., Nagarajan, S., Sood, R., Tosh, C., Kumar, M., Athira, C.K. \& Praveen, A. (2018). Survivability of low pathogenic (H9N2) avian influenza virus in water in the presence of Atyopsis moluccensis (Bamboo shrimp). Zoonoses and Public Health, 65(1), e124-e129. DOI: 10.1111/zph. 12420

Peccia, J., Zulli, A., Brackney, D.E., Grubaugh, N.D., Kaplan, E.H., Casanovas-Massana, A., ... \& Omer, S.B. (2020). Measurement of SARS-CoV-2 RNA in wastewater tracks community infection dynamics. Nature Biotechnology, 38(10), 11641167.

Peiris, J.S.M., Chu, C.M., Cheng, V.C.C., Chan, K.S., Hung, I.F.N., Poon, L.L., ... \& HKU/UCH SARS Study Group. (2003). Clinical progression and viral load in a community outbreak of coronavirusassociated SARS pneumonia: a prospective study. The Lancet, 361(9371), 1767-1772.

Pinon, A., \& Vialette, M. (2018). Survival of viruses in water. Intervirology, 61(5), 214-222.

Pressman, P., Naidu, A.S. \& Clemens, R. (2020). COVID19 and food safety: risk management and future considerations. Nutrition Today, 55(3), 125-128. DOI: 10.1097/NT.0000000000000415

Pung, R., Chiew, C.J., Young, B.E., Chin, S., Chen, M.I., Clapham, H.E., ... \& Low, M. (2020). Investigation of three clusters of COVID-19 in Singapore: implications for surveillance and response measures. The Lancet, 395(10229), 1039-1046.

Qu, G., Li, X., Hu, L. \& Jiang, G. (2020). An imperative need for research on the role of environmental factors in transmission of novel coronavirus (COVID-19). Environmental Science \& Technology, 54(7), 3730-3732

Randazzo, W., Truchado, P., Cuevas-Ferrando, E., Simón, P., Allende, A. \& Sánchez, G. (2020). SARS-CoV2 RNA in wastewater anticipated COVID-19 occurrence in a low prevalence area. Water Research, 15(81), 115942.

Rimoin, A.W., Mulembakani, P.M., Johnston, S.C., Smith, J.O.L., Kisalu, N.K., Kinkela, T.L., ... \& Muyembe, J.J. (2010). Major increase in human monkeypox incidence 30 years after smallpox vaccination campaigns cease in the Democratic Republic of Congo. Proceedings of the National Academy of Sciences, 107(37), 16262-16267.

Rizou, M., Galanakis, I.M., Aldawoud, T.M. \& Galanakis, C.M. (2020). Safety of foods, food supply chain and environment within the COVID-19 pandemic. Trends in Food Science \& Technology, 102, 293299.

Roche, B., Lebarbenchon, C., Gauthier-Clerc, M., Chang, C.M., Thomas, F., Renaud, F., ... \& Guegan, J.F. (2009). Water-borne transmission drives avian influenza dynamics in wild birds: the case of the 2005-2006 epidemics in the Camargue area. Infection, Genetics and Evolution, 9(5), 800-805.

Root, J.J., Bentler, K.T., Shriner, S.A., Mooers, N.L., VanDalen, K.K., Sullivan, H.J., ... \& Franklin, A.B. (2014). Ecological routes of avian influenza virus transmission to a common mesopredator: an experimental evaluation of alternatives. Plos One, 9(8), e102964.

Roy Chowdhury, I., Yeddula, S.G.R. \& Kim, S.H. (2019) Pathogenicity and transmissibility of North American H7 low pathogenic avian influenza viruses in chickens and turkeys. Viruses, 11(2), 163.

Scholtissek, C. \& Naylor, E. (1988). Fish farming and influenza pandemics. Nature, 331(6153), 215-215.

Seymour, I.J. \& Appleton, H. (2001). Foodborne viruses and fresh produce. Journal of Applied Microbiology, 91(5), 759-773.

Seymour, N., Yavelak, M., Christian, C. \& Chapman, B. (2020). COVID-19 and food safety FAQ: Is 
coronavirus a concern with takeout? https://edis.ifas.ufl.edu/fs349.

Shahbaz, M., Bilal, M., Akhlaq, M., Moiz, A., Zubair, S. \& Iqbal, H.M. (2020). Strategic measures for food processing and manufacturing facilities to combat coronavirus pandemic (COVID-19). Journal of Pure and Applied Microbiology, 14(2), 1087-1094.

Shahidi, F. (2020). Does COVID-19 Affect food safety and security? Journal of Food Bioactives, 9.

Shao, Z.J., Zhang, L., Xu, J.Q., Xu, D.Z., Men, K., Zhang, J.X., ... \& Yan, Y.P. (2011). Mother-to-infant transmission of hepatitis B virus: a Chinese experience. Journal of Medical Virology, 83(5), 791795.

Sharma, P., Tripathi, S., Patel, S.K., Dhama, K. \& Chandra, R. (2020). SARS-CoV-2/COVID-19 and its transmission. Prevention, Treatment and Control-An Update, Journal of Pure and Applied Microbiology, 14(suppl 1), 945-956.

Siddell, S., Wege, H. \& Ter Meulen, V. (1983). The biology of coronaviruses. Journal of General Virology, 64(4), 761-776.

Siddell, S.G. (1995). The coronaviridae. In The coronaviridae (pp. 1-10). Springer, Boston, MA.

Silverman, A.I. \& Boehm, A.B. (2020). Systematic review and meta-analysis of the persistence and disinfection of human coronaviruses and their viral surrogates in water and wastewater. Environmental Science \& Technology Letters, 7(8), 544-553

Skraber, S., Schijven, J., Gantzer, C. \& Husman, A.D.R. (2005). Pathogenic viruses in drinking-water biofilms: a public health risk? Biofilms, 2(2), 105.

Stallknecht, D.E., Kearney, M.T., Shane, S.M. \& Zwank, P.J. (1990). Effects of $\mathrm{pH}$, temperature, and salinity on persistence of avian influenza viruses in water. Avian Diseases, 412-418.

Stumpf, P., Failing, K., Papp, T., Nazir, J., Böhm, R. \& Marschang, R.E. (2010). Accumulation of a low pathogenic avian influenza virus in zebra mussels (Dreissena polymorpha). Avian Diseases, 54(4), 1183-1190.

Taştan, C., Yurtsever, B., Karakuş, G.S., Kançaği, D. D., Demir, S., Abanuz, S., ... \& Ovali, E. (2020). SARS-CoV-2 isolation and propagation from Turkish COVID-19 patients. Turkish Journal of Biology, 44(3), 192.

Tennant, B.J., Gaskell, R.M. \& Gaskell, C.J. (1994) Studies on the survival of canine coronavirus under different environmental conditions. Veterinary Microbiology, 42(2-3), 255-259.

Thanapongtharm, W., Van Boeckel, T.P., Biradar, C., Xiao, X. \& Gilbert, M. (2013). Rivers and flooded areas identified by medium-resolution remote sensing improve risk prediction of the highly pathogenic avian influenza $\mathrm{H} 5 \mathrm{~N} 1$ in Thailand. Geospatial Health, 8(1), 193

Tian, X., Li, C., Huang, A., Xia, S., Lu, S., Shi, Z., ... \& Ying, T. (2020). Potent binding of 2019 novel coronavirus spike protein by a SARS coronavirusspecific human monoclonal antibody. Emerging Microbes \& Infections, 9(1), 382-385.

Todd, E.C. \& Grieg, J.D. (2015). Viruses of foodborne origin: a review. Virus Adaptation and Treatment, 7 , 25-45.
Tumpey, T.M., Basler, C.F., Aguilar, P.V., Zeng, H., Solórzano, A., Swayne, D.E., ... \& Garcia-Sastre, A. (2005). Characterization of the reconstructed 1918 Spanish influenza pandemic virus. Science, 310(5745), 77-80.

Vabret, A., Dina, J., Gouarin, S., Petitjean, J., Corbet, S. \& Freymuth, F. (2006). Detection of the new human coronavirus HKU1: a report of 6 cases. Clinical Infectious Diseases, 42(5), 634-639.

Van Doremalen, N., Bushmaker, T., Morris, D.H., Holbrook, M.G., Gamble, A., Williamson, B.N., ... \& Munster, V.J. (2020). Aerosol and surface stability of SARS-CoV-2 as compared with SARSCoV-1. New England Journal of Medicine, 382(16), 1564-1567.

Van Doremalen, N., Miazgowicz, K.L., Milne-Price, S., Bushmaker, T., Robertson, S., Scott, D., ... \& Munster, V.J. (2014). Host species restriction of Middle East respiratory syndrome coronavirus through its receptor, dipeptidyl peptidase 4. Journal of Virology, 88(16), 9220-9232.

Walker, J.S., Archer, J., Gregson, F.K., Michel, S.E., Bzdek, B.R. \& Reid, J. P. (2021). Accurate Representations of the Microphysical Processes Occurring during the Transport of Exhaled Aerosols and Droplets. ACS Central Science, 7(1), 200-209. DOI: 10.1021/acscentsci.0c01522

Wang, H., Sikora, P., Rutgersson, C., Lindh, M., Brodin, T., Björlenius, B., ... \& Norder, H. (2018). Differential removal of human pathogenic viruses from sewage by conventional and ozone treatments. International Journal of Hygiene And Environmental Health, 221(3), 479-488.

Wang, M., Yan, M., Xu, H., Liang, W., Kan, B., Zheng, B., ... \& Wang, H. (2005). SARS-CoV infection in a restaurant from palm civet. Emerging Infectious Diseases, 11(12), 1860.

Weber, D.J., Rutala, W.A., Fischer, W.A., Kanamori, H., \& Sickbert-Bennett, E.E. (2016). Emerging infectious diseases: Focus on infection control issues for novel coronaviruses (Severe Acute Respiratory Syndrome-CoV and Middle East Respiratory Syndrome-CoV), hemorrhagic fever viruses (Lassa and Ebola), and highly pathogenic avian influenza viruses, A (H5N1) and A (H7N9). American Journal of Infection Control, 44(5), 91-100.

Webster, R.G. (1994). While awaiting the next pandemic of influenza. BMJ, 309,1179.

Webster, R.G., Yakhno, M., Hinshaw, V.S., Bean, W.J. \& Murti, K.C. (1978). Intestinal influenza: replication and characterization of influenza viruses in ducks. Virology, 84(2), 268-278.

WHO. (2008). Viruses in food: scientific advice to support risk management activities-Meeting report.

WHO. (2015). WHO estimates of the global burden of foodborne diseases. Foodborne Disease Burden Epidemiology Reference Group, 2007-2015.

WHO. (2019). World Health Organization Sanitaton fact sheet. Available from: https://www.who.int/newsroom/fact-sheets/detail/sanitation [accessed 20.03.20]

WHO. (2020). COVID-19 and food safety: Guidance for food businesses. https://www.who.int/publicationsdetail/covid-19-and-food-safety-guidance-for-foodbusinesses. 
Wigginton, K.R., Ye, Y. \& Ellenberg, R.M. (2015). Emerging investigators series: the source and fate of pandemic viruses in the urban water cycle. Environmental Science: Water Research \& Technology, 1(6), 735-746.

Wolfe, N.D., Daszak, P., Kilpatrick, A.M. \& Burke, D.S. (2005). Bushmeat hunting, deforestation, and prediction of zoonotic disease. Emerging Infectious Diseases, 11(12), 1822.

Wu, F., Xiao, A., Zhang, J., Gu, X., Lee, W. L., Kauffman, K., ... \& Alm, E. (2020b). SARS-CoV-2 titers in wastewater are higher than expected from clinically confirmed cases. MedRxiv, DOI: 10.1101/2020.04.05.20051540

Wu, Y., Guo, C., Tang, L., Hong, Z., Zhou, J., Dong, X., ... \& Huang, X. (2020a). Prolonged presence of SARS-CoV-2 viral RNA in faecal samples. The Lancet Gastroenterology \& Hepatology, 5(5), 434435.

Wurtzer, S., Marechal, V., Mouchel, J.M. \& Moulin, L. (2020). Time course quantitative detection of SARSCoV-2 in Parisian wastewaters correlates with COVID-19 confirmed cases. MedRxiv, 2020.04.05.20051540.

Xiao, F., Sun, J., Xu, Y., Li, F., Huang, X., Li, H., ... \& Zhao, J. (2020a). Infectious SARS-CoV-2 in feces of patient with severe COVID-19. Emerging Infectious Diseases, 26(8), 1920.

Xiao, F., Tang, M., Zheng, X., Liu, Y., Li, X. \& Shan, H. (2020b). Evidence for gastrointestinal infection of SARS-CoV-2. Gastroenterology, 158(6), 18311833.

Ye, Y., Ellenberg, R.M., Graham, K.E. \& Wigginton, K.R. (2016). Survivability, partitioning, and recovery of enveloped viruses in untreated municipal wastewater. Environmental Science \& Technology, 50(10), 5077-5085.

Yekta, R., Vahid-Dastjerdi, L., Norouzbeigi, S., \& Mortazavian, A.M. (2020). Food products as potential carriers of SARS-CoV-2. Food Control, 107754. DOI: 10.1016/j.foodcont.2020.107754

Yeo, C., Kaushal, S. \& Yeo, D. (2020). Enteric involvement of coronaviruses: is faecal-oral transmission of SARS-CoV-2 possible? The lancet Gastroenterology \& hepatology, 5(4), 335-337.

Yezli, S. \& Otter, J.A. (2011). Minimum infective dose of the major human respiratory and enteric viruses transmitted through food and the environment. Food and Environmental Virology, 3(1), 1-30.

Zehra, Z., Luthra, M., Siddiqui, S. M., Shamsi, A., Gaur, N. \& Islam, A. (2020). Corona virus versus existence of human on the earth: A computational and biophysical approach. International Journal of Biological Macromolecules, 161, 271-281.

Zhang, T., Bi, Y., Tian, H., Li, X., Liu, D., Wu, Y., ... \& Xu, B. (2014). Human infection with influenza virus A (H10N8) from live poultry markets, China, 2014. Emerging Infectious Diseases, 20(12), 2076.

Zhang, X., Cai, H., Hu, J., Lian, J., Gu, J., Zhang, S., ... \& Yang, Y. (2020). Epidemiological, clinical characteristics of cases of SARS-CoV-2 infection with abnormal imaging findings. International Journal of Infectious Diseases, 94, 81-87.
Zheng, S., Fan, J., Yu, F., Feng, B., Lou, B., Zou, Q., ... \& Liang, T. (2020). Viral load dynamics and disease severity in patients infected with SARS-CoV-2 in Zhejiang province, China, January-March 2020: retrospective cohort study. BMJ, 369. DOI: 10.1136/bmj.m1443 